\title{
Microbiological and enzymatic studies during the development of an 'Iru' (a local Nigerian indigenous fermented condiment) like condiment from Bambara Nut [Voandzeia subterranea (L) Thours]
}

\author{
Fadahunsi, I. F. and Olubunmi, P. Duyilemi. \\ Department of Botany and Microbiology,University of Ibadan,Oyo State,Nigeria. \\ E-mail: sanmifadahunsi@yahoo.com \\ Received 7 March 2009; received in revised form 15 August 2009; accepted 30 October 2009
}

\begin{abstract}
Fifteen isolates were obtained from a-96 h spontaneously fermented bambara nut to produce an 'Iru' like condiment. Pure cultures of the isolates were identified employing API $50 \mathrm{CH}$ strips and API CHL medium (API system, Montalieu, Vercieu, France). Their identities were confirmed as Bacillus subtilis, Bacillus licheniformis and Bacillus pumilus. The total microbial counts showed that the microbial load increased significantly from $3.2 \times 10^{5} \pm 0.11 \mathrm{cfu} / \mathrm{g}$ at $0 \mathrm{~h}$ to $9.2 \times 10^{7}$ $\pm 0.20 \mathrm{cfu} / \mathrm{g}$ at $96 \mathrm{~h}(p \leq 0.05)$. The investigation into enzymatic activities during product development revealed that the amylase activity fluctuated, by increasing significantly from $0.33 \pm 0.1 \times \mathrm{s}$ unit g/dry wt at $0 \mathrm{~h}$ to $0.39 \pm 0.04 \times \mathrm{s}$ unit g/dry wt at $60 \mathrm{~h}$ which finally decreased to $0.32 \pm 0.08 \times \mathrm{s}$ unit g/dry wt at the end of fermentation. Proteinase activity showed that at $0 \mathrm{~h}$ an activity of $0.22 \pm 0.09 \times \mathrm{s}$ unit g/dry wt was recorded, which increased significantly to $0.24 \pm 0.06 \times \mathrm{s}$ unit $\mathrm{g} / \mathrm{dry}$ wt at $24 \mathrm{~h}$. This value decreased significantly to $0.21 \pm 0.03 \times \mathrm{s}$ unit g/dry wt at $48 \mathrm{~h}$ which increased significantly to $0.28 \pm 0.08 \times \mathrm{s}$ unit $\mathrm{g} / \mathrm{dry}$ wt at $96 \mathrm{~h}$. However, the lipase which was observed at $0 \mathrm{~h}$ to show an activity of $0.50 \pm 0.05 \mathrm{x}$ $\mathrm{s}$ unit $\mathrm{g} / \mathrm{dry}$ wt increased significantly to $0.80 \pm 0.06 \times \mathrm{s}$ unit $\mathrm{g} / \mathrm{dry}$ wt at $72 \mathrm{~h}$ and decreased to $0.70 \pm 0.08 \times \mathrm{s}$ unit $\mathrm{g} / \mathrm{dry}$ wt at the end of production period.
\end{abstract}

Keywords: condiment, microbiology, enzyme, Bambara nut, 'Iru', fermentation

\section{INTRODUCTION}

Bambara nut (Vigna subterranea (L) Verdc. Syn. Voandzeia subterranea (L) Thours) belongs to the family leguminosae and subfamily papilionoideae (Goli and $\mathrm{Ng}$ 1988; Goli et al., 1991; Heller et al., 1995). Despite its adaptability to harsh conditions, bambara nut have lost importance in many parts of Africa due to introduction and expanded production of groundnut (Kay, 1979) In recent years, there had been renewed interest in the cultivation of the crop because of its ability to resist drought conditions and to yield a reasonable crop when grown on such poor soils where groundnut have failed to grow (Kay, 1979).

Cereals and other plant foods may contain significant amount of toxic or antinutritional substances. In this regards, legumes have been reported, particularly as rich sources of natural toxicans including protease inhibitors, amylase inhibitors, metal chelates, flatus factors, haemagglutinnis, sapronins, cyanogens, lathyrogens, tannis, allergens, acetylenic furan and isoflavonoid phytoalexins which limit utilization of legume (Pariza, 1996; Haard et al., 1999). These toxic components were documented to interfere with digestive processes involving enzymatic degradation.

Bambara nut remains one of the most neglected crop in terms of research programme (Swanevelder, 1998). However, empirical evidence and fragmentary research results suggest it is a crop with great potentials (Swanevelder, 1998). In Africa this crop was described as the second most important food legume and the third most important crop after maize (Swanevelder, 1998).

Bambara nut and cowpea were reported as important source of proteins and carbohydrates (Borget, 1989; Minka and Bruneteau, 2000). Their protein composition is over 22\%, consisting of essential amino acid predominantly lysine and leucine (Minka and Bruneteau, 2000). Due to their protein content, they are used occasionally as substitutes for meat or fish (CampbellPlatt, 1980).

Despite the nutritional potential of this pulse and coupled with its resemblance to soybeans both in texture and colour, there is a death of information on the extensive utilization of bambara nut for the production of fermented foods in sub-Saharan Africa.

This study was carried out to investigate the microbiological and enzymatic aspect of the development of an 'Iru' like condiment from this pulse.

\section{MATERIALS AND METHODS}

\section{Collection of samples}

Bambara nut (Sokoto white cultivar (SW) was purchased from Bodija market Ibadan, Nigeria. The healthy seeds 
were selected and stored inside a sterile nylon bag and kept in the refrigerator at $4{ }^{\circ} \mathrm{C}$.

\section{Preparation of bambara nut for fermentation}

Forty grams of the beans was thoroughly washed in clean water and then soaked in distilled water $(500 \mathrm{~mL})$ for $24 \mathrm{~h}$. The nuts were dehulled manually by pressing in between fingers. The dehulled beans were boiled in distilled water for $15 \mathrm{~min}$. The boiled water was decanted and the nuts were spread on ethanol - sterilized tray to dry for $30 \mathrm{~min}$ and wrapped with leaves of banana (Musa - Sapientum) which had been previously washed, cleaned and surface sterilized with $75 \%$ ethanol (Odunfa, 1981). The wrapped beans were transferred into ethanol-sterilised calabash which were covered with another sterile calabash and finally placed in a sterile black polythene bag and tied firmly. The set-up was then kept on a surface sterilized laboratory bench to ferment naturally at room temperature $\left(30+2^{\circ} \mathrm{C}\right)$ for $96 \mathrm{~h}$.

\section{Isolation procedure}

The medium used for isolation was nutrient agar (NA) (Lab M). One gm of the fermenting bambara nut was transferred aspectically into $10 \mathrm{~mL}$ of sterile saline solution in a test-tube and shaken vigorously to dislodge the associated microorganisms. The homogenate was serially diluted with sterile distilled water and $1 \mathrm{~mL}\left(10^{-4}\right.$ dilution) was taken and plated on Petri-dishes containing sterile nutrient agar. Incubation was carried out at room $\left(30 \pm 2{ }^{\circ} \mathrm{C}\right)$. The plates were examined for growth and microbial load determined by physical counting. The pure cultures were obtained by streaking repeatedly. All treatments were carried out in replicates. Samples were taken at $12 \mathrm{~h}$ interval.

\section{Identification of organisms}

Identification of the isolates was carried out using the API $50 \mathrm{CH}$ strips and API CHL medium (API System, Montalieu, Vercieu, France)

\section{Enzyme assay during Fermentation}

\section{Extraction of enzyme}

Five grams of $24 \mathrm{~h}$ fermented samples was ground in a mortar with pestle in $20 \mathrm{~mL}$ distilled water. The suspension was centrifuged at $5000 \mathrm{rpm}$ in a MSE high speed -18 refrigerated centrifuge at $5^{\circ} \mathrm{C}$ for $30 \mathrm{~min}$. The supernatant was recovered and stored in a freezer at -2 ${ }^{\circ} \mathrm{C}$.

\section{Amylase Assay}

Amylase activity was determined using DNSA method of Bernfeld (1955). The amount of reducing sugar formed was calculated from a standard curve constructed with known concentrations of maltose.

\section{Proteinase Assay}

Proteinase activity was determined employing the procedure described by Young and Woods (1977). The extracting buffer was $0.1 \mathrm{M}$ sodium hydrogen phosphate solution (pH 6.5). Five $\mathrm{mL}$ of the extract was added to 10 $\mathrm{mL}$ of $2 \%$ casein solution and incubated at $35{ }^{\circ} \mathrm{C}$ for 30 $\mathrm{min}$ and the reaction was terminated by the addition of 10 $\mathrm{mL}$ of $10 \%$ trichloroacetic acid solution. The reaction mixture was filtered through Whatman No 1, filter paper and the optical density read at $275 \mathrm{~nm}$ using CampsecM105 spectrophotometer

\section{Lipase assay}

This assay was carried out according to the modified methods of Somkuti and Babel (1967) A unit of lipase activity is defined as the amount of sodium hydroxide $(\mathrm{NaOH})$ used in the titration to bring the reaction mixture to a $\mathrm{pH} 9.5$ under the defined assay condition (Young and Woods, 1977).

\section{RESULTS AND DISCUSSION}

Bambara nut was allowed to ferment naturally for $96 \mathrm{~h}$. Pure cultures of the fourteen isolates obtained were identified by employing the API $50 \mathrm{CH}$ strips and API CHL medium (API system Montalieu, Vercieu, France). Their identities were confirmed as Bacillus subtilis, $B$. licheniformis and B. pumilus.

The total viable microbial count recorded revealed that this parameter, increased significantly from $3.2 \times 10^{5}$ $\pm 0.11 \mathrm{cfu} / \mathrm{mL}$ at $0 \mathrm{~h}$ to $9.2 \times 10^{7} \pm 0.20 \mathrm{cfu} / \mathrm{mL}$ at $96 \mathrm{~h}(p \leq$ 0.05).

Table 1: Total viable microbial count during fermentation

\begin{tabular}{cc}
\hline Time $(\mathrm{h})$ & Microbial load $(\mathrm{cfu} / \mathrm{g})$ \\
\hline 0 & $3.2 \times 10^{5} \mathrm{a}$ \\
12 & $8.0 \times 10^{5} \mathrm{~b}$ \\
24 & $2.0 \times 10^{6} \mathrm{c}$ \\
36 & $5.0 \times 10^{6} \mathrm{~d}$ \\
48 & $9.0 \times 10^{6} \mathrm{e}$ \\
60 & $1.1 \times 10^{\prime} \mathrm{f}$ \\
72 & $3.0 \times 10^{7} \mathrm{~g}$ \\
84 & $6.0 \times 10^{7} \mathrm{~h}$ \\
96 & $9.2 \times 10^{1} \mathrm{i}$ \\
\hline
\end{tabular}

Note: Means followed by the same letters are not significant by Duncan's Multiple Range test at $5 \%$ level of significance.

The isolation of Bacillus species observed in this study had been previously reported by Odunfa (1981); Popoola and Akueshi (1984); Antai and Ibrahim (1986); Ogbadu and Okagbue (1988); Sanni and Ogbonna 1991); Uzogara et al., (1991); Achinehwu, (1992); Barimalaa et al. (1994); Ogbonna et al. (2001); Omafuvbe et al. (2002); in their various studies on condiment production from fermented vegetable proteins. 


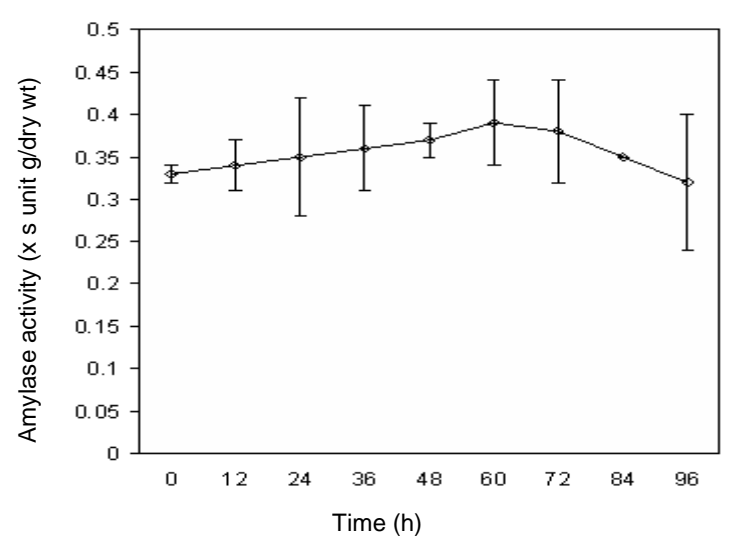

Figure 1: Changes in amylase activity during production of condiment

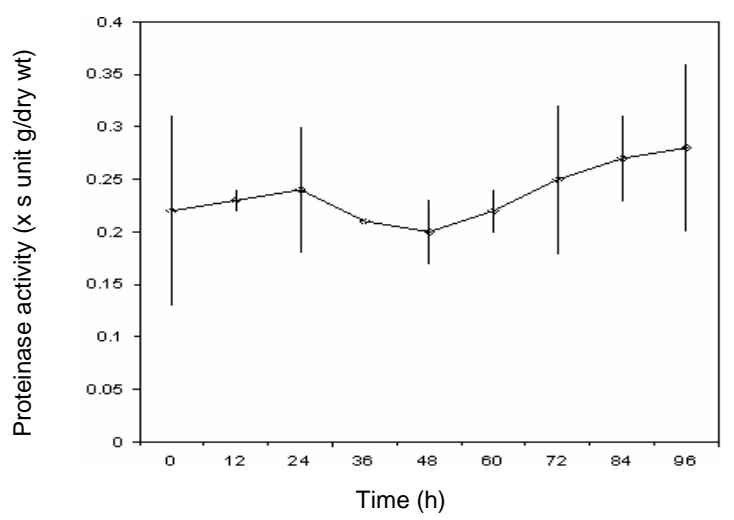

Figure 2: Proteinase activity monitoring during product development

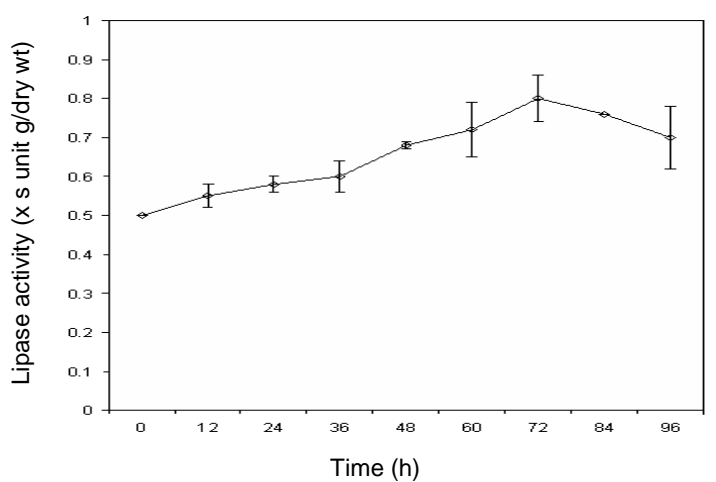

Figure 3: Lipase assay during fermentation of bambara nut

This occurrence might be due to shorter time of boiling and as well as the composition and texture of the beans. In addition, they might have originated from air, soil or normal contaminants of the calabash and leaves employed in the fermentation process.

The determination of enzymatic activities during the production period showed that the amylase activity increased significantly from $0.33 \pm 0.01 \times s$ unit $\mathrm{g} / \mathrm{dry}$ wt at $0 \mathrm{~h}$ to $0.39 \pm 0.047 \times \mathrm{s}$ unit $\mathrm{g} / \mathrm{dry}$ wt at $60 \mathrm{~h}$ which finally decreased significantly to $0.32 \pm 0.08 \times \mathrm{s}$ unit $\mathrm{g} / \mathrm{dry}$ wt at the end of the fermentation period (Figure 1) $(p \leq 0.05)$.

The amylase monitoring procedure revealed that the bacillus species are amylolytic (Omafuvbe et al., 2000; Kiers et al., 2000). The amylase activity increased to $72 \mathrm{~h}$ during fermentation and dropped. This observation was earlier documented by Odunfa (1981) and Omafuvbe et al., (2004) and substantiated this finding as resulting in increased total reducing sugar.

However, the proteinase assay showed that at $0 \mathrm{~h}$ an activity of $0.22 \pm 0.09 \times \mathrm{s}$ unit $\mathrm{g} /$ dry wt was recorded which increased significantly to $0.24 \pm 0.06 \times \mathrm{s}$ unit $\mathrm{g} / \mathrm{dry}$ wt at $24 \mathrm{~h}$. This value decreased to $0.22 \pm 0.00 \times \mathrm{s}$ unit $\mathrm{g} / \mathrm{dry}$ wt at $60 \mathrm{~h}$ and finally increased to $0.28 \pm 0.08 \times \mathrm{s}$ unit $\mathrm{g} / \mathrm{dry}$ wt at the end of the fermentation period (Figure 2).

This observation confirms the earlier submissions of Omafuvbe et al. (1999; 2000; 2004). The rapid increase in the total amino acids was adduced to be responsible for this finding (Sarkar et al., 1993; Omafuvbe et al., 2002; 2004).

Figure 3 shows the result of the lipase activity, which was observed at $0 \mathrm{~h}$ to reflect an activity of $0.50 \pm 0.00 \times \mathrm{s}$ unit $\mathrm{g} / \mathrm{dry}$ wt which increased significantly to $0.80 \pm 0.06 \mathrm{x}$ $s$ unit g/dry wt $72 \mathrm{~h}$ and decreased to $0.70 \pm 0.08 \times \mathrm{s}$ unit $\mathrm{g} /$ dry wt at the end of the fermentation process.

However the highest lipase activity was recorded at 72 h. Odunfa, $(1983 ; 1985)$ reported low levels of lipase activity in Parkia biglobosa during dawadawa production and melon seed fermentation respectively, while Njoku and Okamadu (1989) observed minimal lipase activity during development of 'Ugba' from Pentachletera macrophyla. Young and Wood (1977) and Odunfa (1983; 1985) submitted that low lipase activity during fermentation of vegetable proteins has been discovered to reduce the problems of objectionable taste and development of rancidity.

\section{REFERENCES}

Achinewu, S. C. (1992). Composition and food potential of the African oil bean (Pentacletera macrophylla) and velvet bean (Mucuna uriens). Journal of Food Science 27, 1736-1737.

Antai, S. P. and Ibrahim, M. H. (1986). Microorganisms associated with African locus bean (Pakia fillicoidea Welw) Fermentation for dawadawa production. Journal of Applied Bacteriology 61, 145-148.

Barimalaa, I. S., Achinewhu, S. C., Yibutana, I. and Amadi, E. N. (1994). Studies on the solid substrate fermentation of Bambara groundnut. Science Food Agriculture 66, 443-453.

Bernfeld, P. C. (1955). Enzymes of starch degradation and synthesis. Advanced Enzymology 12, 379-428.

Borget, M. (1989). Les legumineuses vivriere tropicales. France, Maison neuve et Larose et ACCT.

Campbell-Platt, G. (1980). African locus bean (Parkia spp.) and its West - African fermented food product, 'dawadawa'. Ecology Food Nutrition 9, 123-132. 
Goli, A. E. and Ng, N. Q. (1988). Bambara groundnut multi-location yield trial. In: Annual Report, Genetic Resources Units, IITA. 1987, 11-12.

Goli, A. E. Begemann, F. and Ng, N. Q. (1991). Germplasm diversity in Bambara groundnut and prospects for crop improvement. In: Crop Genetic Resources of Africa. Chapter 3, Vol. 2. Ng, N. Q., Perrino, P., Attere F. and Zedan, H. (eds.). IITA, IBPGR, UNEP, CNR. pp. 195-202.

Haard, N. F., Odunfa, S. A., Cherlo-Holl,V.B., QuinteroRamirez R., Lorence-Quinones, A. and WacherRadarte, C. (1999). Fermented Cereals: A global perspective. FAO Agricultural Services Bulletin No $138 \mathrm{FAO} / \mathrm{UN}$ Rome Italy.

Heller, J. Begemam, F. and Mushonga, J. (1995). International plant Genetic Resources Institute promoting the Conservation and use of under utilized and neglected crops (9). Proceedings of the workshop on conservation and improvement of Bambara groundnut. 14-16 Nov. 1995, Harare, Zimbabwe. pp. 16.

Kay, D. E. (1979). Bambara groundnut: Food legumes. TPI Crop Digest No. 3 Tropical Products Institute, London. pp. 17-22.

Kiers, J. L., Nouts, R. M. J. and Rombouts, F. M. (2000). in vitro digestibility of processed and fermented soyabean, cowpea and maize. Journal of Science of Food and Agriculture 80, 1325-1331.

Minka, S. R. and Bruneteau, M. (2000). Partial chemical composition of Bambara pea (Vigna subterranean (L.) Verde). Food Chemistry. 68, 273-276

Njoku, H. O. and Okamadu C. P. (1989). Biochemical changes during the natural fermentation of the African oil bean for the production of 'Ugba' Journal of Science Food Agriculture. 49, 457-465.

Odunfa, S. A. (1981). Microbiology and amino acid composition of ogiri a Fermented Melon (Citrullus vulgaris). Plant Foods for Human Nutrition 23, 15-18

Odunfa, S. A. (1983). Biochemical changes during production of ogiri, a fermented melon (Citrullus vulgaris schard) product. Plant Foods for Human Nutrition 32, 11-18.

Odunfa, S. A. (1985). Biochemical changes during 'Iru' fermentation. Journal of Food Technology 20, 295303.

Ogbadu, L. and Okagbue, R. N. (1988). Bacterial fermentation of soybeans for dawadawa production. Journal of Applied Bacteriology 65, 353-356.

Ogbonna, D. N., Sokari, T. G., and Achinewhu, S. C. (2001). Development of an owoh, type product from African yam beans (Sphenostylis stenocarpa) Hoechstex. A. Rich (Harius) by solid substrate fermentation. Plants foods Human Nutrition 56, 183194.

Omafuvbe, B. O., Abiose, S. H. and Adaraloye O. O. (1999). The production of fepaye - a fermented condiment from Prosopis africana Taub seeds. International Journal of Food Microbiology 51, 183186.
Omafuvbe, B. O., Shounkan, O. O. and Abiose, S. H. (2000). Microbiological and biochemical changes in the fermentation of soybean (Glycine max) for soydaddawa production by starter cultures of Bacillus. Food Microbiology 19, 561-566.

Omafuvbe, B. O., Abiose, S. H. and Shounkan, O. O. (2002). Fermentation of soybean (Glycine max) for soy-dadawa production by starter cultures of Bacillus sp. Food Microbiology 19, 456-651.

Omafuvbe, B. O., Falade, S. O., Osuntogun, B. A. and Adewusi, R. A. (2004). Chemical and Biochemical changes in African locus beans (Pakia biglobosa) and melon (Citrullus vulgaris) seeds during Fermentation to Condiments. Parkistan Journal of Nutrition 3, 140145.

Pariza, M. W. (1996). Toxic substances. Food Chemistry New York, Marcel Dekker. pp. 825-840.

Popoola, T. O. S. and Akueshi, C. O. (1984). Microorganism associated with the fermentation of soybeans for the production of dawadawa (a condiment). Nigeria Food Journal 283, 194-196.

Sanni, A. I. and Ogbonna, D. N. (1991). Biochemical studies on owoh a Nigerian fermented soup condiment from cottonseed. Food Microbiology 9, 177-183.

Sarkar, P. K., Tamang, J. P., Cook, P. E. and Owens, J.D. (1993). Kinema a traditional fermented food. Proximate composition and microflora. Food Microbiology 11, 47-55.

Somkuti, G. A. and Babel, F. J. (1967). Conditions influencing the synthesis protease by Mucor pusillus. Applied Microbiology 15, 1309-1312.

Swanevelder, C. J. (1998). Bambara - Food for Africa (Vigna subterranean-bambara groundnut). South Africa.

Uzogara, S. G., Agu, L. N. and Uzogara, E. O. (1991). A review of traditional fermented foods, condiments and beverages in Nigeria. Their benefits and possible problems. Ecology Food Nutrition 24, 267-288.

Young, F. M. and Wood, B. J. (1977). Microbiology and Biochemistry of 'soy' - 'sauce' fermentation. Advanced Applied Microbiology 17, 157-194. 